\title{
Peach Rust (Transchelia spp.) ${ }^{1}$
}

\section{Daniel Mancero-Castillo, Ali Sarkhosh, Courtney Ligon, Mercy Olmstead, and Philip Harmon²}

\section{Introduction}

Peach rust is a fungal disease commonly caused by Tranzchelia discolor (Fuckel) (Adaskaveg et al. 2000) that attacks plants in the genus Prunus, including peach, nectarine, almond, plum, apricot, and cherry. In the southeastern United States, the fungus is most common in peach orchards during the summer and fall. Peach rust severity depends on the climatic conditions (temperature and rainfall), hosts (peach cultivars), and geographic location. The disease is spread by airborne spores, which depend on moisture for infection. Where warm temperatures and high rainfall occur, severe peach rust infections usually result. Florida's summer rainfall provides favorable conditions for peach rust development. All currently available peach cultivars in Florida are susceptible to the disease. Management practices such as sanitation, scouting for disease, and fungicide applications before harvest help reduce the adverse impacts of this disease.

In temperate climates, peach rust fungi present four spore stages: urediniospores, teliospores, basidiospores, and aeciospores (Cummins and Hiratsuka 1983); however, the disease is mainly a management concern in high rainfall years (Soto-Estrada et al. 2005). In contrast, in subtropical growing regions, urediniospores are the main type of inoculum of peach rust. Peach rust is considered an important foliar disease in both tropical and subtropical climates every year due to high temperature and humidity (Alves et al. 2014)

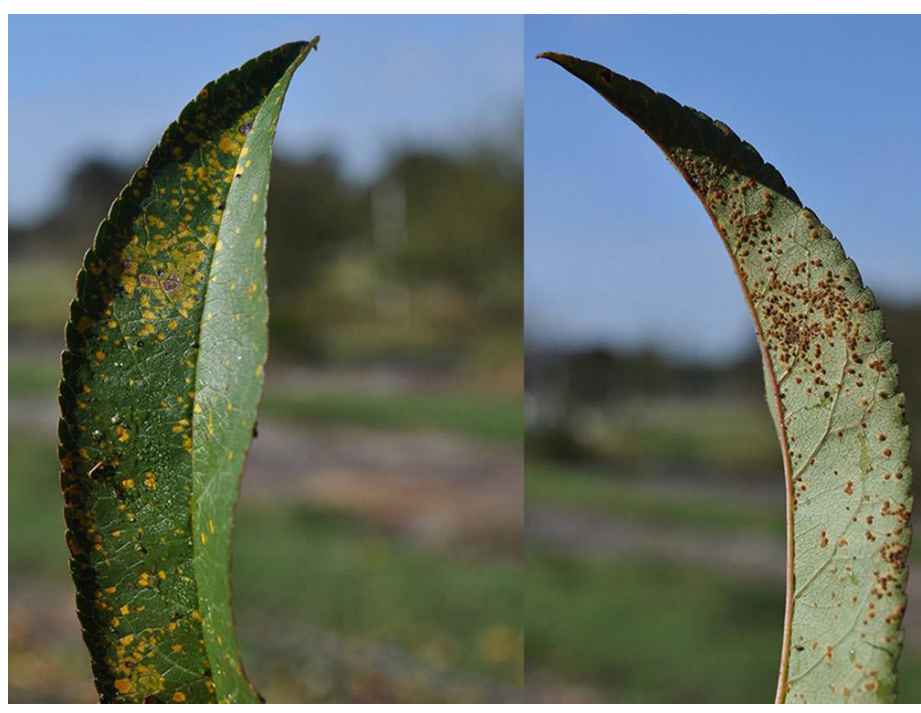

Figure 1. Peach leaf rust symptoms showing small yellow necrotic areas on the surface on the left (axial side) and rust-colored fungal spores on the underside on the right (abaxial side).

Credits: Mercy Olmstead

Ecologically, rust is considered a biotroph, which requires living host tissue for survival. Peach rust symptoms mainly occur on the leaves of peach trees (Figure 1), where multiple disease cycles occur during a growing season. Occasionally, young twigs or fruit can be infected through stomata (Soto-Estrada et al. 2005). Orchards with severe symptoms can suffer significant economic losses due to premature defoliation. In addition, early budbreak in late autumn and induction of early budburst and bloom may reduce the cropping potential for the subsequent season up to $45 \%$ in severe cases (Adaskaveg et al. 2000; Alves and May-De Mio 2008).

1. This document is HS1263, one of a series of the Horticultural Sciences Department, UF/IFAS Extension. Original publication date June 2015. Revised July 2018. Visit the EDIS website at http://edis.ifas.ufl.edu.

2. Daniel Mancero-Castillo, student; Ali Sarkhosh, assistant professor and Extension specialist; Courtney Ligon, former student; Mercy Olmstead, former assistant professor and Extension specialist; Horticultural Sciences Department; Philip Harmon, professor and Extension specialist, Plant Pathology Department; UF/IFAS Extension, Gainesville, FL 32611

The Institute of Food and Agricultural Sciences (IFAS) is an Equal Opportunity Institution authorized to provide research, educational information and other services

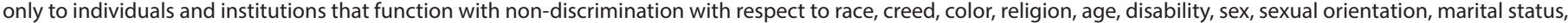
national origin, political opinions or affiliations. For more information on obtaining other UF/IFAS Extension publications, contact your county's UF/IFAS Extension office. U.S. Department of Agriculture, UF/IFAS Extension Service, University of Florida, IFAS, Florida A \& M University Cooperative Extension Program, and Boards of County Commissioners Cooperating. Nick T. Place, dean for UF/IFAS Extension. 


\section{Leaf Symptoms}

Leaf lesions are the most common symptoms of peach rust observed in Florida. Symptoms initiate as pale, chlorotic spots on both leaf surfaces during spring. Leaf lesions continue forming bright yellow and angular lesions (Figure 2). Lesions develop through the summer and into the fall, turning into mature lesions with necrotic yellow halos (Adaskaveg et al. 2000). Lesions on the lower leaf surface develop rust-brown spore masses (Figure 2) similar to those observed on twig cankers. Late in the growing season, leaf lesions may turn dark brown, reddish-to-black as they produce overwintering structures (Adaskaveg et al. 2000). Severe early-season infections can produce premature defoliation, reduced yields, and fruit infections at harvest (Adaskaveg et al. 2012). In Florida, defoliation is the main concern because it reduces yields in the following year. Under the microscope, peach rust urediniospores can be observed showing specific ornamentation (Figure 3).

Disease symptoms may resemble damage caused by other fungal pathogens and insects, so it is important to confirm the diagnosis of rust by sending a plant sample to the UF/ IFAS Plant Diagnostic Center in Gainesville (PDC-GNV) to be tested for rust spores.
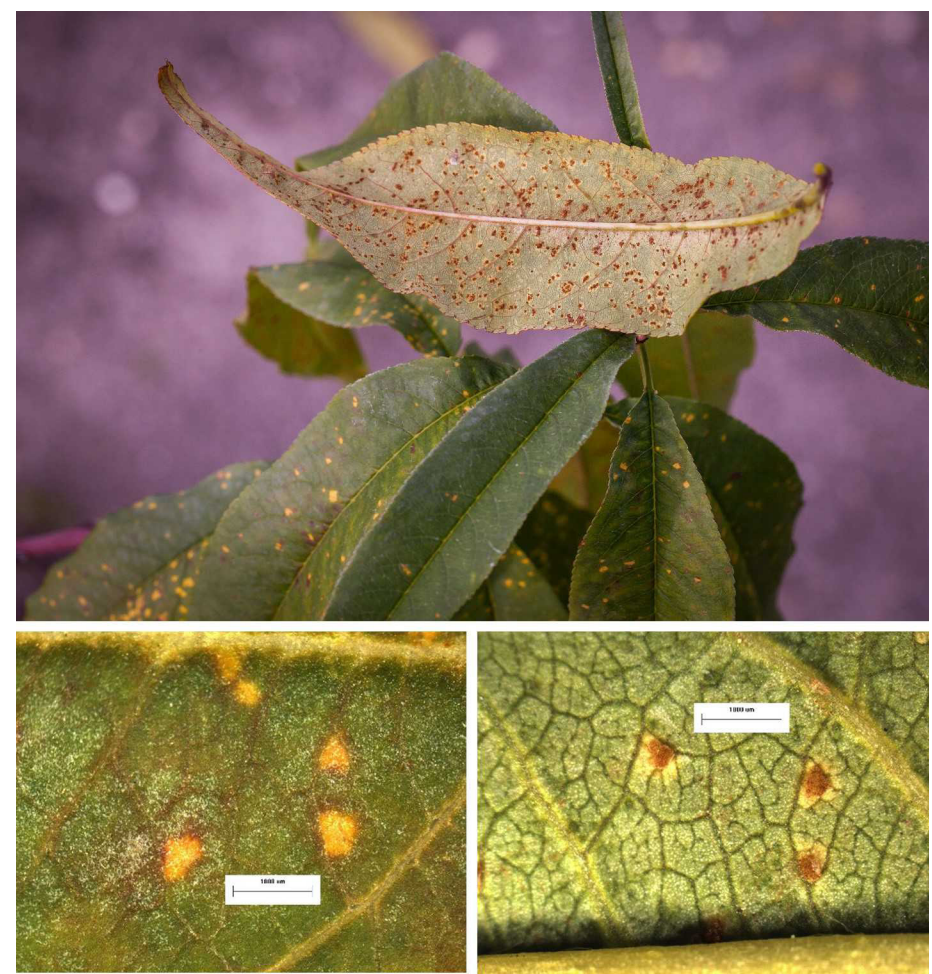

Figure 2. Peach rust leaf symptoms (top), magnified pictures showing small yellow chlorotic areas on leaf top side (left) and rust-colored fungal spores on the leaf underside (right).

Credits: M. Borden
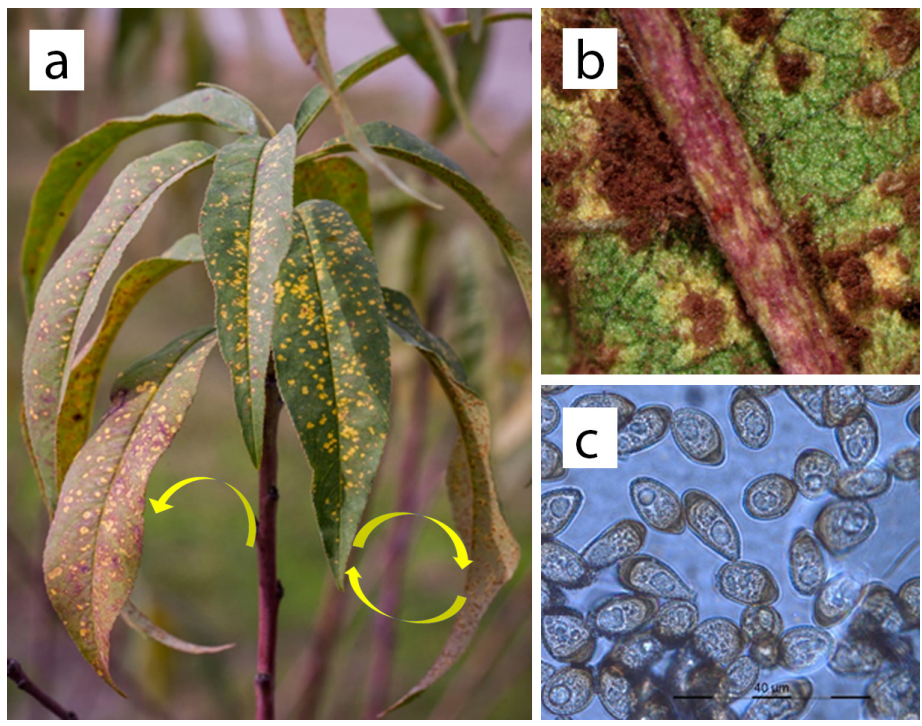

Figure 3. Peach rust (Transchelia spp.) cycle in Florida: a) infected leaves or twigs from previous season serve as primary inoculum; b) rust pustules under the leaves produce urediniospores that reinfect leaves; and c) urediniospores pictured under the microscope. Credits: Image adapted from photos by the UF/IFAS Plant Diagnostic Center

\section{Shoot Symptoms}

Symptoms on young stems start as water-soaked lesions, which develop into splits with uredinia (flacks) formation. Twig cankers appear as blisters, with splits measuring up to $1 / 4$-inch long usually visible on the upper side of the twig (Figure 4; Adaskaveg et al. 2000). After the twig lesions emerge, rusty brown, powdery masses of spores (urediniospores) are produced in the cankers. However, in Florida, twig cankers are not common.

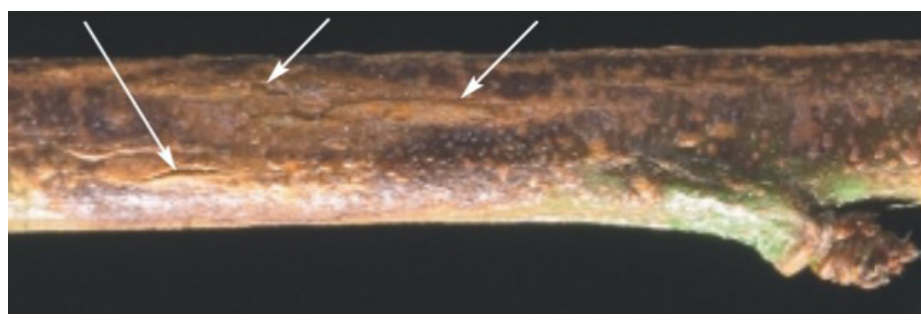

Figure 4. Twig cankers (arrows) caused by the rust fungus T. discolor on a one-year-old peach branch.

Credits: Adaskaveg et al. 2000

\section{Fruit Symptoms}

Fruit lesions may develop during the growing season following leaf symptoms; however, fruit lesions are not often observed in Florida because our varieties are early maturing. If later-maturing varieties are grown, fruit lesions may be observed. On immature, yellow, or green fruit, lesions first develop as small, brownish spots (about 0.1 inch diameter) with green halos (Figure 5). When the fruit 


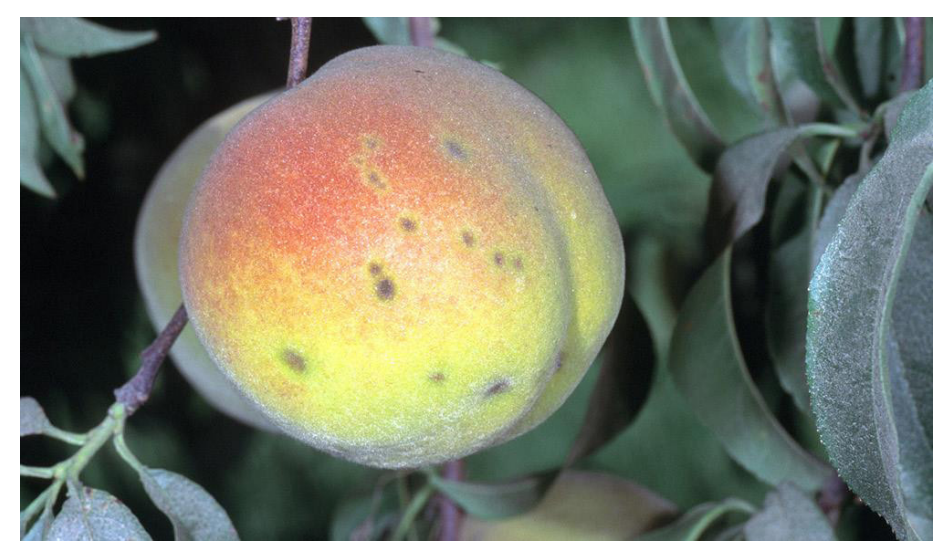

Figure 5. Typical fruit lesions on mature fruit, which is atypical for peach production in Florida.

Credits: Jack Kelly Clark; reproduced by permission from University of California Statewide IPM Program, @ 2002 by Regents, University of California.

matures and develops darker skin color (blush), these lesion halos become greenish-yellow. The lesions are sunken and extend several millimeters into the fruit (Adaskaveg et al. 2012). Numerous infections may develop on each fruit, and these can lead to secondary infections by other fungal species and cause fruit decay.

Fruit symptoms may resemble damage caused by stink bugs, so it is important to confirm the diagnosis of rust by sending a plant sample to the UF/IFAS Plant Diagnostic Center in Gainesville (PDC-GNV) to be tested for rust spores.

\section{Disease Cycle}

The life cycle of Tranzchelia discolor, the causal agent of peach rust, includes multiple spore stages that develop from sexual or asexual reproduction. The spore stages are urediniospores, teliospores, basidiospores, and aeciospores (Adaskaveg et al. 2000). Sexual and asexual cycles are non-exclusive and occur under specific conditions. Peach rust starts when moisture from precipitation or irrigation splashes the spores onto nearby leaves (Figure 5).

In a sexual life cycle, infected peach leaves can produce teliospores, which may overwinter on a peach tree until the next the growing season. If so, teliospores can germinate to produce basidiospores, which are capable of infecting alternate hosts, the identity of which are unknown in Florida. In California, Anemone coronaria (poppy anemone) has been identified as an alternate host of peach rust where basiodiospores are infective and aecio spores are formed. Then, aecio spores can infect peach trees and continue the cycle. Aeciospores can reinfect a peach tree and produce rust lesions with urediniospores in the spring (Adaskaveg et al. 2000).
In the asexual cycle, infected leaf tissue erupts, producing a rust pustule under the leaf. A single rust pustule on the leaf can produce thousands of uredioniospores, which can reinfect peach leaves in favorable conditions.

In subtropical conditions, urediniospores overwinter in twig cankers and pustules under the leaves, producing the primary inoculum for infection in the next growing season (Alves et al. 2015)

The T. discolor cycle between peach and poppy anemone, an alternate host, starts with aeciospore infecting peach leaves and twigs. Urediniospores move from twig to leaf and from leaf to fruit. Late in the season, other urediniospores on leaf develop teliospores, which overwinter and produce basidiospores. Basidiospores can infect the alternate host. Finally, aeciospores are produced on poppy anemone, which restarts the cycle of infecting peach leaves and twigs (Adaskaveg et al. 2000).

\section{Management}

Peach rust phytosanitary management uses fungicide applications in spring (Ellis et al. 2002). This practice increases the risk of developing resistance rust biotypes. Therefore, fungicides should be tank-mixed or rotated according to the specific product labels to reduce the risk of fungicide resistance. See Table 1 for additional product, rate, and timing information. More severe infections in the previous year result in several fungicide applications through the growing season. Fungicide efficacy controlling

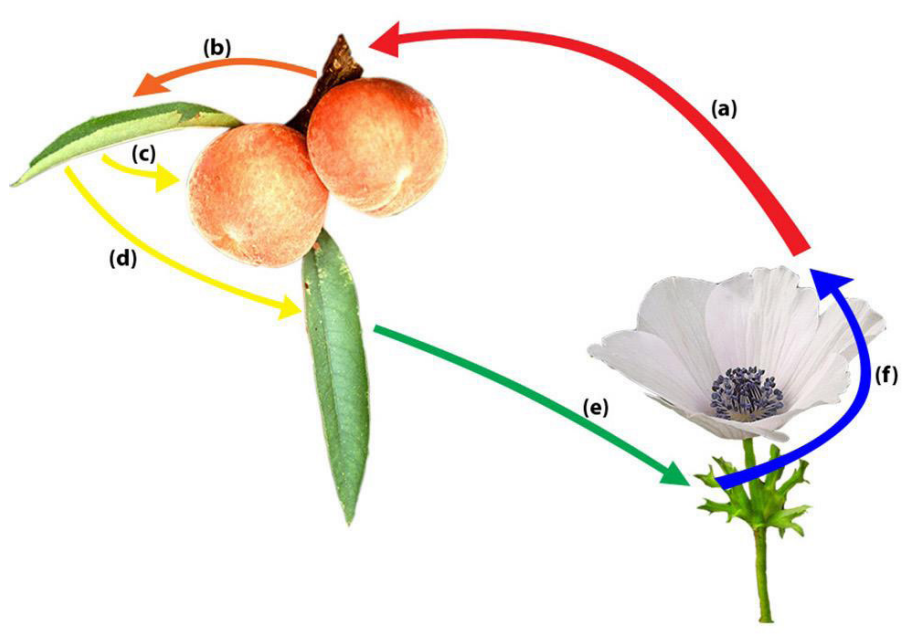

Figure 6. Path of T. discolor between peach and poppy anemone, an alternate host: a) aeciospore infects peach twig; b) urediniospores move from twig to leaf; c) urediniospores move from leaf to fruit; d) other urediniospores on leaf develop teliospores, which are overwintering structures; e) overwintering structures produce basidiospores, which infect the alternate host; and f) aeciospores are produced on poppy anemone, which restart the cycle.

Credits: Image adapted from photos by M. Knight and Z. Evenor 
rust outbreaks are affected by many factors, such as the source of inoculum, the cultivar, weather, tree spacing, and cultural management (Nesi et al. 2014; Kowata et al. 2011).

Control measures must be started before rust symptoms are severe, and multiple applications of fungicides with different modes of action may be required to achieve acceptable disease control. Preventive treatments of Bordeaux and sulfocalcic mixtures at the beginning of the season can help to reduce the initial inoculum (Citadin et al. 2010). Peach rust fungicide application usually starts after the trees leaf out; however, management for peach rust can be combined with peach scab control. Specific fungicides can be effective for both diseases (Table 1). Scouting the peach orchard for early symptoms helps detect the disease early in the season. High relative humidity and leaf wetness favor rust development; therefore, irrigation schedules and sprinkler direction should be managed to reduce wetting of the foliage (Rouse and Roberts 2000).

Treatment with sulfur can be effective and acceptable for use in an organically certified crop. However, sulfur applications at high temperatures $\left(>90^{\circ} \mathrm{F}\right)$ can cause burning symptoms on leaves. Sterol-inhibiting fungicides (Fungicide Resistance Action Committee [FRAC] Code 3 below) are systemic options that are efficacious and generally more expensive than sulfur (Rouse and Roberts 2000). Products listed in Table 1 with active ingredients in the quinone outside inhibitor (QoI) (FRAC Group 11) and succinate dehydrogenase inhibitors (SDHI) FRAC Group 7) have the greatest potential efficacy.

\section{References}

Adaskaveg, J. E., A. Soto-Estrada, H. Forster, D. Thompson, J. Hasey, B. T. Manji, and B. Teviotdale. 2000. Peach Rust Caused by Tranzschelia Discolor in California. Google Books.

Alves, Giselda, and Louise Larissa May-De Mio. 2008. "Efeito Da Desfolha Causada Pela Ferrugem Na Floração E Produtividade Do Pessegueiro.” Revista Brasileira de Fruticultura. 30 (4): 907-12. doi:10.1590/ S0100-29452008000400012.

Alves, Giselda, Cristiano Nunes, Franco Ramos, Emerson Medeiros, and Louise May-de-mio. 2015. "Peach Rust: Performance of Cultivars in Intergrated Production System." Revista Brasileira de Fruticultura. 37(1): 83-89. doi:10.1590/0100-2945-006/14.
Alves, Giselda, Piérri Spolti, Cristiano Nunes Nesi, Emerson Medeiros Del Ponte, and Louise Larissa May De Mio. 2014. "Susceptibility Levels and Grouping of Peach Cultivars in Relation to Peach Rust under Field Conditions." Acta Scientiarum. 36(2): 167. doi:10.4025/actasciagron. v36i2.17268.

Citadin, Idemir, Sérgio Miguel Mazaro, Moeses Andrigo Danner, Maria do Carmo Bassols Raseira, and Gustavo Malagi. 2010. "Variability in Leaf Rust Susceptibility among Peach Cultivars." Revista Ceres. 57(2): 185-93. doi:10.1590/ S0034-737X2010000200008.

Cummins, G. B., and Y. Hiratsuka. 1983. "Illustrated Genera of Rust Fungi." https://www.cabdirect.org/cabdirect/ abstract/19841397268

Ellis, R. P., Micha Bayer, Arnis Druka, Joanne R. Russell, Christine A. Hackett, Jesse Poland, Luke Ramsay et al. 2002. "Phenotype/genotype Associations for Yield and Salt Tolerance in a Barley Mapping Population Segregating for Two Dwarfing Genes." Journal of Experimental Botany. 53(371): 1163-76. doi:10.1093/jexbot/53.371.1163.

Kowata, Ligia Sayko, Lilian Amorim, José Carlos Fachinello, and Louise Larissa May-De Mio. 2011. "Adoption of Integrated Production of Peach System in Paraná State." Bragantia. 70(2): 325-333. doi:10.1590/ S0006-87052011000200011.

Nesi, Cristiano N., Giselda Alves, Paulo Justiniano Ribeiro, and Louise L. May De Mio. 2014. "Heterogeneity of Peach Rust Disease Progress within the Tree Canopy." European Journal of Plant Pathology. 139(4): 663-77. doi:10.1007/ s10658-014-0421-x.

Rouse, Robert E, and Pamela D Roberts. 2000. "Fungicidal Supression of Peach Leaf Rust in Low-Chill Subtropical Grown Peaches." Proc. Fla. State Hort. Soc 113: 37-40.

Soto-Estrada, A., H. Förster, and J. E. Adaskaveg. 2003. "New Fungicides and Application Strategies Based on Inoculum and Precipitation for Managing Stone Fruit Rust on Peach in California." Plant Disease. 87(9): 1094-1101.

Soto-Estrada, A., H. Förster, D. A. Demason, and J. E. Adaskaveg. 2005. "Initial Infection and Colonization of Leaves and Stems of Cling Peach by Tranzschelia Discolor." Phytopathology. 95(8): 942-50. 


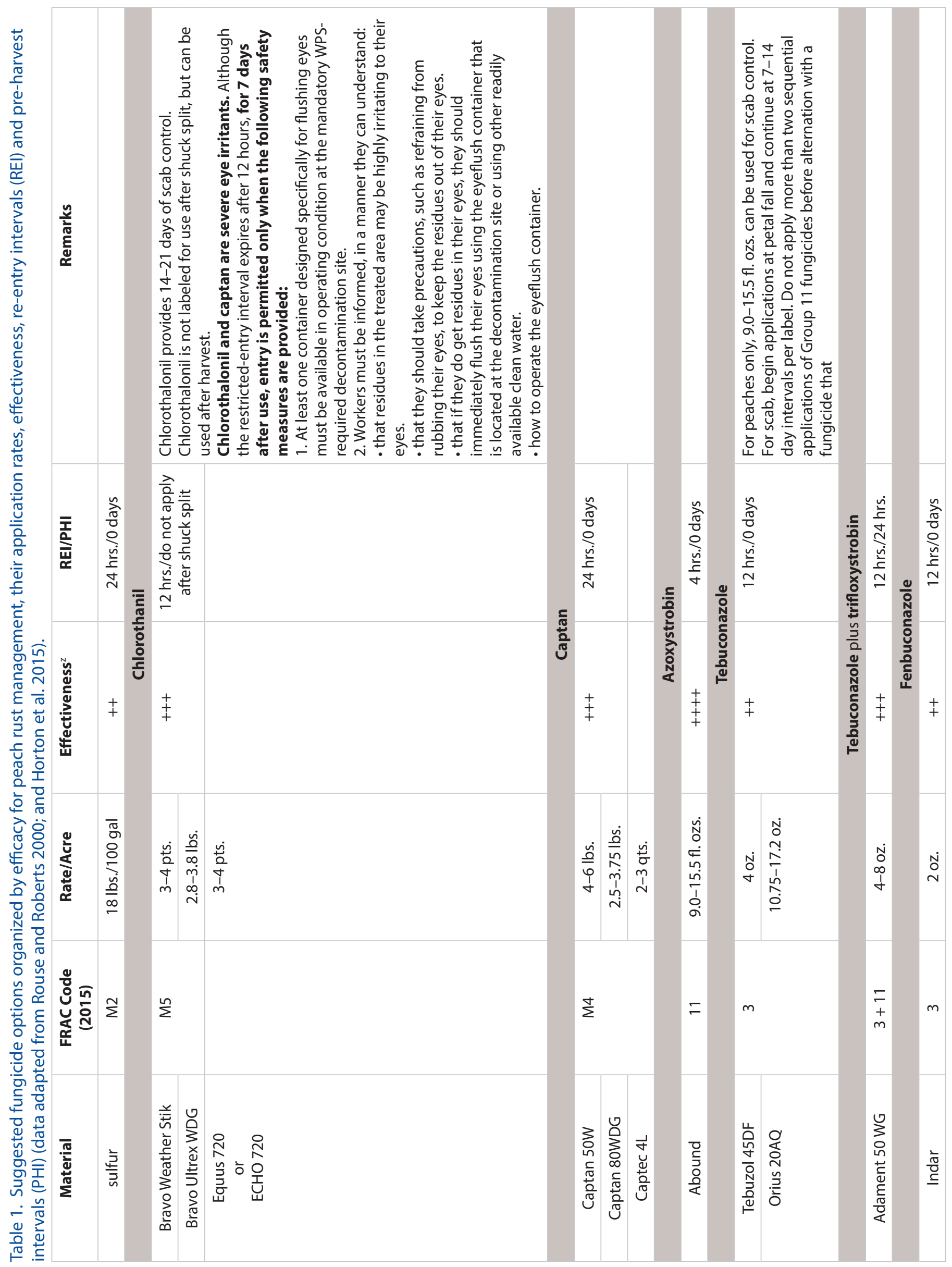




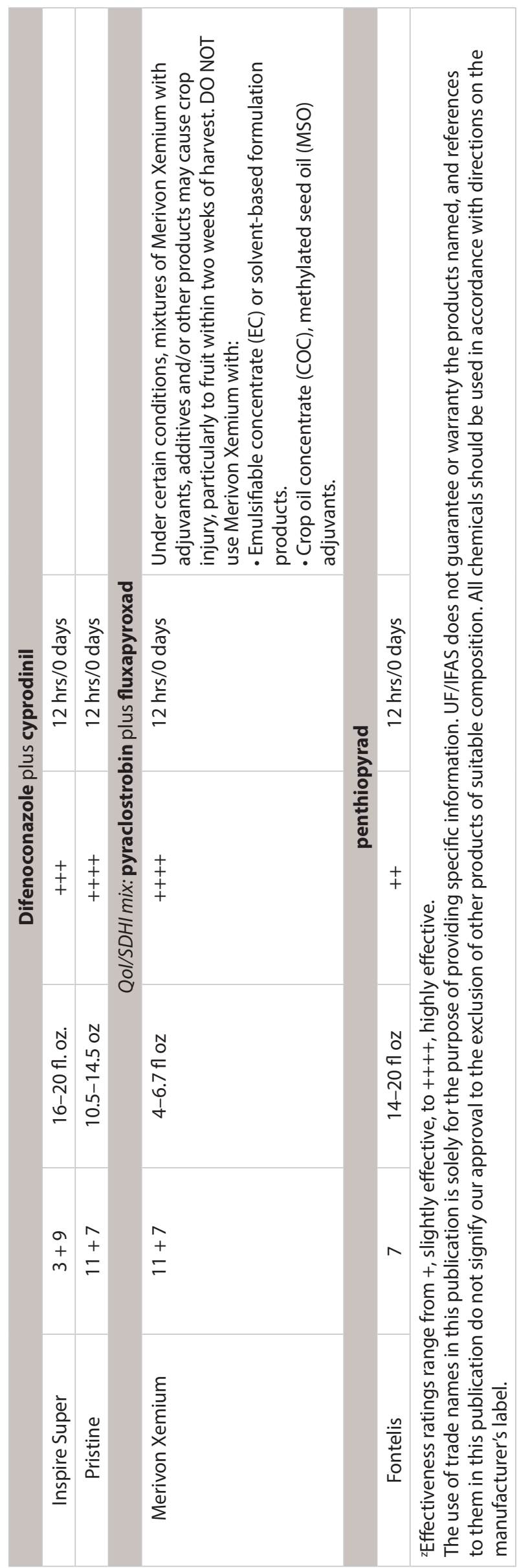

